\title{
Pharmacogenomics of Prostaglandin and Leukotriene Receptors
}

\author{
José A. Cornejo-García ${ }^{1,2 *}$, James R. Perkins ${ }^{1}$, Raquel Jurado-Escobar ${ }^{1}$, \\ Elena García-Martín ${ }^{3}$, José A. Agúndez ${ }^{3}$, Enrique Viguera ${ }^{4}$, Natalia Pérez-Sánchez ${ }^{2}$ and \\ Natalia Blanca-López ${ }^{5}$ \\ ${ }^{1}$ Research Laboratory, International Business Information Management Association (IBIMA)-Regional University Hospital of \\ Malaga, University of Málaga (UMA), Malaga, Spain, ${ }^{2}$ Allergy Unit, International Business Information Management \\ Association (IBIMA)-Regional University Hospital of Malaga, University of Málaga (UMA), Malaga, Spain, ${ }^{3}$ Department of \\ Pharmacology, University of Extremadura, Caceres, Spain, ${ }^{4}$ Genetics Unit, Department of Cell Biology, Genetics and \\ Physiology, Faculty of Sciences, University of Málaga, Malaga, Spain, ${ }^{5}$ Allergy Service, Infanta Leonor University Hospital, \\ Madrid, Spain
}

\section{OPEN ACCESS}

Edited by:

Luis Abel Quiñones,

University of Chile, Chile

Reviewed by:

Bernhard H. Rauch,

University of Greifswald, Germany

Fiorentina Roviezzo,

University of Naples Federico II, Italy

*Correspondence:

José A. Cornejo-García josea.cornejo@gmail.com

Specialty section:

This article was submitted to

Pharmacogenetics and

Pharmacogenomics,

a section of the journal

Frontiers in Pharmacology

Received: 09 May 2016 Accepted: 02 September 2016

Published: 21 September 2016

Citation:

Cornejo-García JA, Perkins JR, Jurado-Escobar R, García-Martín E

Agúndez JA, Viguera $E$,

Pérez-Sánchez N and Blanca-López N

(2016) Pharmacogenomics of

Prostaglandin and Leukotriene

Receptors. Front. Pharmacol. 7:316.

doi: 10.3389/fphar.2016.00316
Individual genetic background together with environmental effects are thought to be behind many human complex diseases. A number of genetic variants, mainly single nucleotide polymorphisms (SNPS), have been shown to be associated with various pathological and inflammatory conditions, representing potential therapeutic targets. Prostaglandins (PTGs) and leukotrienes (LTs) are eicosanoids derived from arachidonic acid and related polyunsaturated fatty acids that participate in both normal homeostasis and inflammatory conditions. These bioactive lipid mediators are synthesized through two major multistep enzymatic pathways: PTGs by cyclooxygenase and LTs by 5-lipoxygenase. The main physiological effects of PTGs include vasodilation and vascular leakage (PTGE2); mast cell maturation, eosinophil recruitment, and allergic responses (PTGD2); vascular and respiratory smooth muscle contraction (PTGF2), and inhibition of platelet aggregation (PTGI2). LTB4 is mainly involved in neutrophil recruitment, vascular leakage, and epithelial barrier function, whereas cysteinyl LTs (CysLTs) (LTC4, LTD4, and LTE4) induce bronchoconstriction and neutrophil extravasation, and also participate in vascular leakage. PTGs and LTs exert their biological functions by binding to cognate receptors, which belong to the seven transmembrane, $G$ protein-coupled receptor superfamily. SNPs in genes encoding these receptors may influence their functionality and have a role in disease susceptibility and drug treatment response. In this review we summarize SNPs in PTGs and LTs receptors and their relevance in human diseases. We also provide information on gene expression. Finally, we speculate on future directions for this topic.

Keywords: prostaglandins, leukotrienes, eicosanoid receptors polymorphisms, inflammation, NSAID-hypersensitivity

\section{INTRODUCTION}

Arachidonic acid is released from cell membrane phospholipids by phospholipase A2 in response to different stimuli, and then oxidized through cyclooxygenase (COX)-1 or 5-lipoxygenase (5LO) to produce prostaglandins (PTGs) and leukotrienes (LTs), respectively (Capra et al., 2015). Although these bioactive lipid mediators, collectively named eicosanoids, are associated with homeostasis they also play a key role in inflammation. 
The COX-1 pathway firstly leads to the formation of prostanoids with the PTGH2 endoperoxide intermediate, that is metabolized to PTGD2, PTGE2, PTGF2a, PTGI2, and thromboxane (TX)A2 by specific synthases. The main physiological effects of PTGs include vasodilation and vascular leakage (PTGE2); mast cell maturation, eosinophil recruitment and allergic responses (PTGD2); vascular and respiratory smooth muscle contraction (PTGF2), and inhibition of platelet aggregation (PTGI2) (Claar et al., 2015).

LTs can be grouped into the chemoattractant LTB4 and the cysteinyl LTs (CysLTs): LTC4, LTD4, and LTE4. LTB4 is mainly involved in neutrophil recruitment, vascular leakage, and epithelial barrier function, whereas CysLTs induce bronchoconstriction and neutrophil extravasation, and also participate in vascular leakage (Singh et al., 2013).

PTGs and LTs exert their biological functions by binding to cognate receptors belonging to the seven transmembrane G protein-coupled receptor superfamily (GPCRs): PTGFR and PTGIR for PTGF and PTGI2, respectively; PTGDR and CRTH2 (chemoattractant receptor-homologous molecule expressed on Th2 cells) for PTGD; PTGER1 to PTGER4 for PTGE; and TXA2R for TXA2 (Thompson et al., 2014). LTB receptors are BLTR1 and BLTR2, and CysLTR1 and CysLTR2 for CysLTs.

In addition to the environment, human complex diseases are also affected by individual factors including genetic background. In fact, a number of genetic variants, mainly single nucleotide polymorphisms (SNPs), have been consistently associated with different pathological and inflammatory conditions, representing potential targets for therapy. SNPs in genes encoding PTG and LT receptors may influence their functionality and have a role in disease susceptibility and treatment response. In this review we summarize current knowledge regarding SNPs in PTGs and LTs receptors and their association with human inflammatory conditions (Table 1), with a special focus on hypersensitivity to non-steroidal anti-inflammatory drugs (NSAIDs), the most common type of drug hypersensitivity.

\section{PTG, TBXA2, AND LT RECEPTOR POLYMORPHISMS IN INFLAMMATORY CONDITIONS}

\section{PTGFR, PTGIR, PTGDR, and CRTH2}

Current data concerning PTGFR genetic variation supports its relationship with variability in treatment response to latanoprost, a commonly prescribed antiglaucomatous drug, although the mechanisms underlying this association are unknown (Gao et al., 2015; Ussa et al., 2015).

PTGI2 (prostacyclin) plays a key role in the cardiovascular system through the specific inhibition of platelet aggregation and its vasodilatory effects on smooth muscle (Dorris and Peebles, 2012). The polymorphism A984C in PTGIR has been associated with platelet aggregation and may play a role in cerebral infarction (Shimizu et al., 2013). Two synonymous variants in this gene (V53V and S328S) have also been associated with enhanced platelet activation in patients with deep vein thrombosis (Patrignani et al., 2008).
An important genomic region on chromosome 14 that includes PTGDR has been linked to asthma and atopy (1997; Mansur et al., 1999; Hakonarson et al., 2002). There are conflicting results concerning the association of promoter variants influencing the transcription of this gene with these phenotypes. For example, some studies have failed to associate two variants in PTGDR $(-441 \mathrm{C}>\mathrm{T}$ and $-197 \mathrm{TC}>\mathrm{T})$ with asthma using family-based or case-control analyses in Latinos and African American asthmatics (Tsai et al., 2006). In addition, particular PTGDR haplotypes could not be associated with Chinese children with asthma and atopy (Leung et al., 2009), or with two Australian populations of asthmatics (Jamrozik et al., 2011), with similar data having been previously reported in a distinct Chinese population ( $\mathrm{Li}$ et al., 2007). However, $-441 \mathrm{C}>\mathrm{T},-197 \mathrm{TC}>\mathrm{T},-549 \mathrm{~T}>\mathrm{C}$, and various haplotypes have been associated with asthma in two ethnically different populations (Oguma et al., 2004). Moreover, the $-197 \mathrm{~T}>\mathrm{C}$ and $-613 \mathrm{C}>\mathrm{T}$ polymorphisms have been significantly associated with allergic asthma, and allergy to pollen and mites, respectively (Isidoro-García et al., 2011). The same authors also found that the PTGDR diplotype CCCT/CCCC (-613CC, -549CC, $-441 \mathrm{CC}$, and -197TC), with a potential influence on gene transcription, was more frequent in patients with nasal polyposis, with or without asthma, and in patients suffering from the aspirin triad (Benito Pescador et al., 2012). In addition to these SNPs in PTGDR, the promoter polymorphism $-731 \mathrm{~A}>\mathrm{G}$ and the intronic variant $6651 \mathrm{C}>\mathrm{T}$ were found to be associated with asthma, atopic asthma, and bronchial hyperreactivity in families from UK, with similar results for $6651 \mathrm{C}>\mathrm{T}$ in a Danish study (Zhu et al., 2007). The intronic variants rs17831675 and rs17831682 in PTGDR have also been associated with asthma susceptibility (Ungvári et al., 2012). These variants, as well as rs17125273, also appear to have some relevance with respect to IgE levels in asthmatics (Ungvári et al., 2012).

Different studies have shown certain polymorphisms in CRTH2 (rs11571288, rs545659, and rs634681) to be associated with asthma and allergic sensitization in different populations (Huang et al., 2004; Cameron et al., 2009; Wang et al., 2009). A functional study showed that in addition to being linked with asthma, the $1544 \mathrm{G}-1651 \mathrm{G}$ haplotype in the CRTH2 $3^{\prime}$ UTR increased mRNA stability, supporting its role as a strong candidate gene for asthma (Huang et al., 2004). In another study the rs533116 variant was associated with a higher proportion of CRTh2 cells during Th2 differentiation as well as increased IL4 and IL-13 expression levels after agonist stimulation (Campos Alberto et al., 2012). The minor allele of CRTH2 1431G $>\mathrm{C}$ has been also associated with levels of specific IgE to food allergens in a population of German children (Cameron et al., 2009).

\section{PTGE Receptors}

Considering the great variety of biological functions carried out by PTGE it is not surprising that SNPs in its receptors appear to have a role in different pathologies. For example, the rs17197 polymorphism in the $3^{\prime}$-UTR of PTGER2 has been associated with essential hypertension in men (Sato et al., 2007), and the intronic rs2268062 variant in PTGER3 with hypertension in a separate study (Sõber et al., 2009). The latter may be explained 
TABLE 1 | Main prostaglandin and leukotriene polymorphisms associated with different human inflammatory conditions.

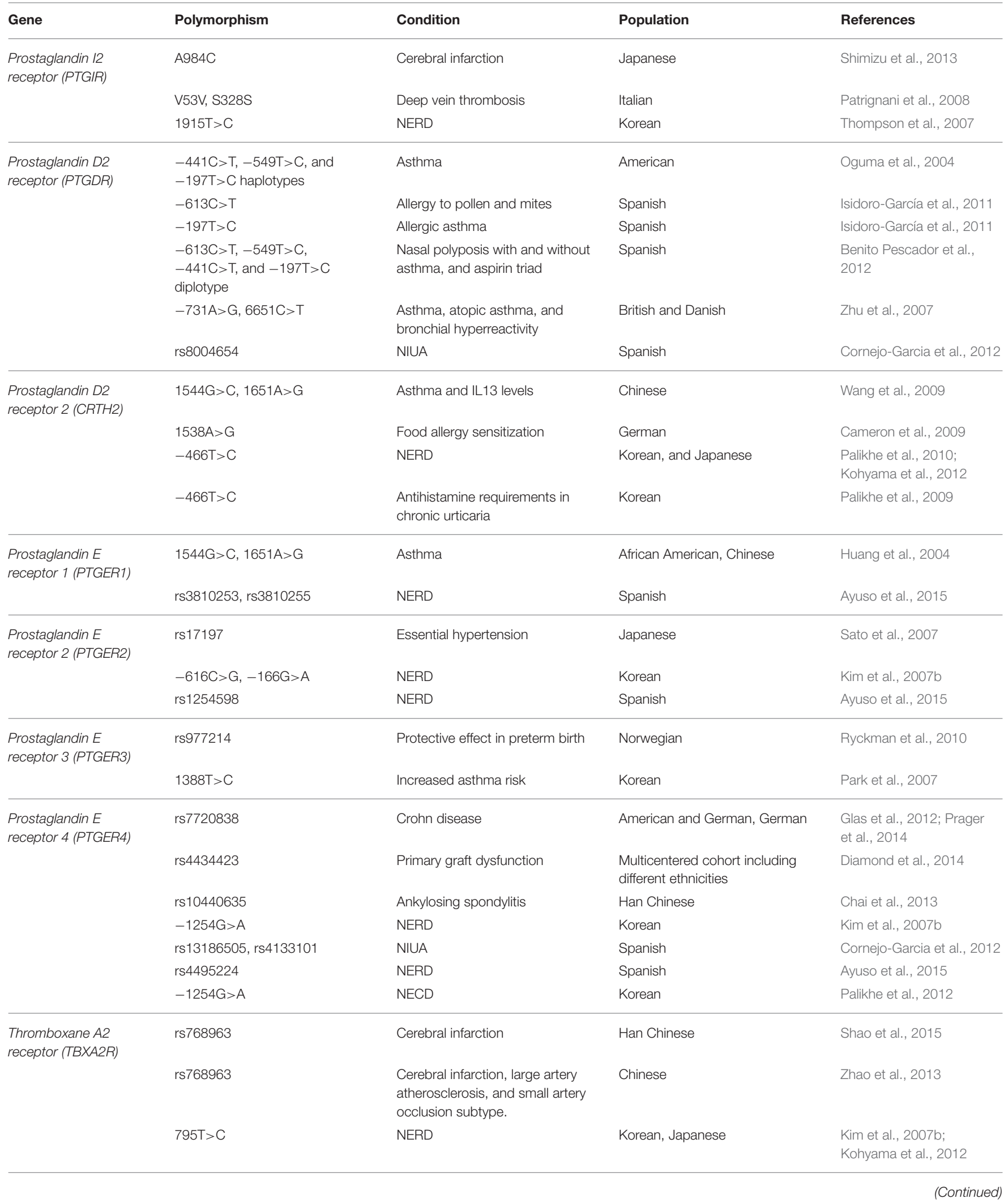


TABLE 1 | Continued

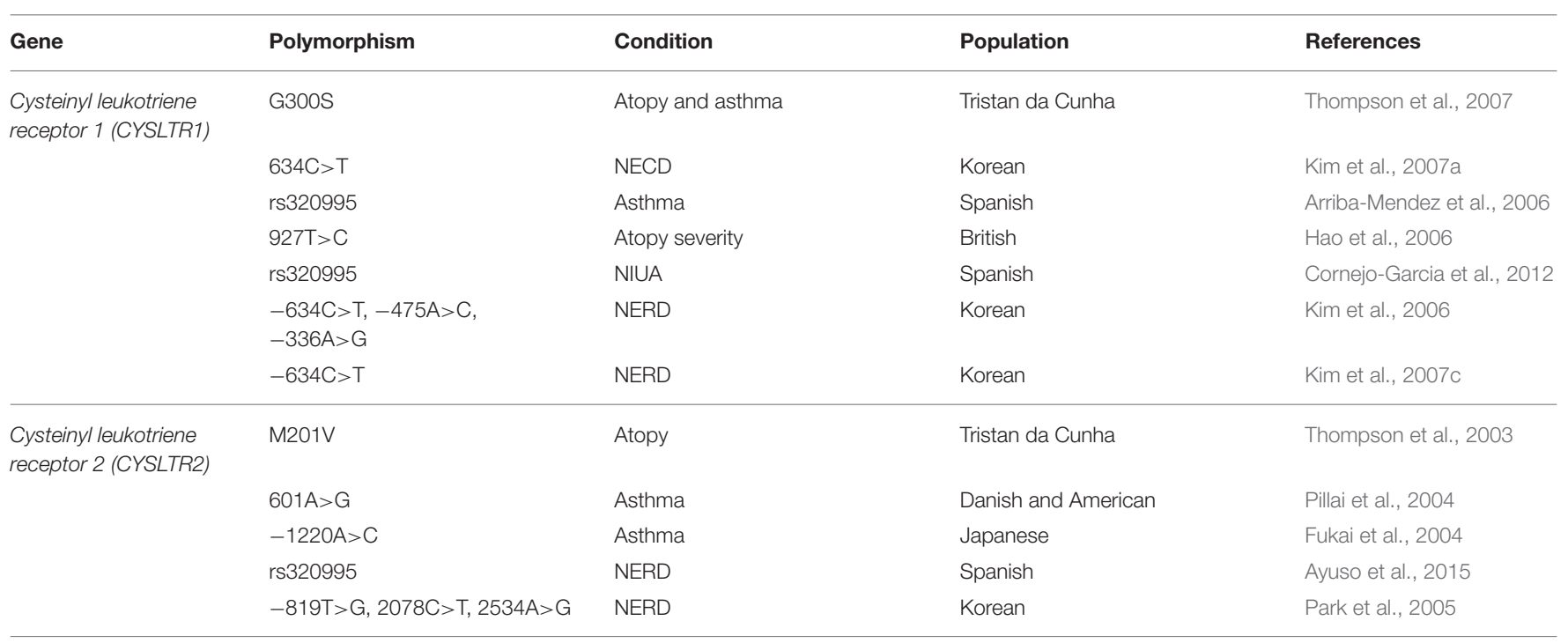

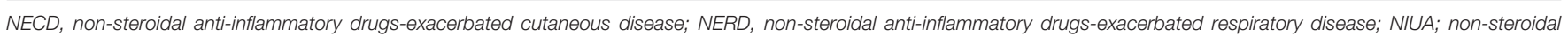
anti-inflammatory drugs-induced urticaria/angioedema.

by the role of this gene in neurotransmitter release modulation in central and peripheral neurons, and in the inhibition of sodium and water reabsorption in kidney (Breyer and Breyer, 2000). A protective effect in preterm birth has been suggested for the minor allele of rs977214 in PTGER3 (Ryckman et al., 2010).

Concerning asthma, a Bayesian analysis found an association for several SNPs in PTGER2 (rs12587410, rs17197, rs1254600, rs708498) (Ungvári et al., 2012). A Korean study showed the promoter variant $\mathrm{rs} 207579(-616 \mathrm{C}>\mathrm{G})$ in PTGER2 to be associated with increased asthma risk whereas two variants in the 3'-UTR of PTGER3 (rs959 and rs34745168) were associated with a diminished risk (Park et al., 2007).

Environmental and genetic determinants affecting PTGER4 expression might be thought to be crucial in a plethora of diseases, giving the central role of its ligand, PTGE2, in immunomodulation and control of inflammation (Soontrapa et al., 2011; Tang et al., 2012; Konya et al., 2013). For example, it has been shown for Crohn's disease that disease-associated alleles in a gene-desert region in 5p13.1 correlate with expression levels of PTGER4, the closest gene to this region (Libioulle et al., 2007). Through a meta-analysis of genome wide association studies and replication studies, rs11742570 in PTGER4 was recently found to be associated with inflammatory bowel disease (Jostins et al., 2012).

Two polymorphisms in PTGER4 (rs4495224 and rs7720838) have been associated with susceptibility to Crohn's disease in three independent cohorts (Glas et al., 2012). Using in silico analysis the authors predicted these SNPs to be crucial components of binding sites for the transcription factors NF$\kappa \mathrm{B}$ and XBP1 with higher binding scores for carriers of the risk alleles, which could explain how these SNPs contribute to increased PTGER4 expression (Glas et al., 2012). Notably, the association of PTGER4 rs7720838 with Crohn's disease has recently been replicated in other populations (Prager et al., 2014).
Although the molecular link between genetic variation and altered regulatory $\mathrm{T}$ cell function in primary graft dysfunction has not been uncovered, a recent study showed the major allele of the rs4434423 variant in PTGER4 to be associated with their differential suppressive functions in this pathology (Diamond et al., 2014).

Finally, another SNP in PTGER4 (rs10440635) has been associated with ankylosing spondylitis severity in a Han Chinese population (Chai et al., 2013).

\section{TXA2R}

TXA2R plays a central role in atherosclerosis and thrombosis (Capra et al., 2014). It has been recently demonstrated that the promoter polymorphism rs768963 is more frequent among Han Chinese who have suffered from cerebral infarction (Shao et al., 2015). Cells containing two exonic variants (C795T and $\mathrm{T} 924 \mathrm{C}$ ) showed an increased ligand binding-induced intracellular calcium influx and fibrinogen-integrin conjugation, suggesting that TXA2R SNPs may influence platelet function and the risk of developing cerebral ischemia (Shao et al., 2015). In another study the C allele of rs768963 was associated with large artery atherosclerosis and small artery occlusion subtypes (Zhao et al., 2013).

The variants V80E and A160T in TBXA2R showed opposing roles on platelet activity, inhibiting and promoting platelet activation respectively (Gleim et al., 2013). The TBXA2R 924TT genotype has been associated with residual platelet activity after off-pump artery bypass grafting (Wang et al., 2013), and with resistance to aspirin (Gao et al., 2011). This genotype also showed less effectiveness in platelet aggregation (Fujiwara et al., 2007). Homozygosity for the minor allele of the C795T, C924T or the G1686A TBXA2R SNPs was associated with a decreased expression of CD62P in agonist stimulated platelets (Fontana 
et al., 2006). Finally, the TBXA2R SNP rs13306046 was associated with decreased blood pressure (Nossent et al., 2011).

A recent meta-analysis has shown an association between the TBXA2R 924C $>\mathrm{T}$ polymorphism and asthma (Pan et al., 2016). Asthmatic children with combinations of the TBXA2R $795 \mathrm{~T}>\mathrm{C}$ and $924 \mathrm{~T}>\mathrm{C}$ risk alleles had higher total IgE levels, total eosinophil counts, and lower FEV1 than those carrying the common alleles (Kim et al., 2008). The minor allele frequency of $T B X A 2 R \quad 795 \mathrm{~T}>\mathrm{C}$ was significantly higher in NSAIDsexacerbated respiratory disease (NERD) patients compared with aspirin-tolerant asthmatics and homozygous patients for the $\mathrm{C}$ allele had a greater percent fall of FEV1 compared with carriers of the CT or TT genotypes (Kim et al., 2005). A significant association was also observed between the TBXA2R T924C polymorphism and FEV1 in children with atopic asthma (Leung et al., 2002; Hong et al., 2005).

Two haplotypes involving four intronic SNPs (rs2238631, rs2238632, rs2238633, and rs2238634) influenced transcriptional activity and were associated with asthma-related phenotypes (Takeuchi et al., 2013). These SNPs are in linkage disequilibrium with the exonic SNPs rs11318632 and rs4523. The first one was associated with atopic asthma (Shin et al., 2003), and the latter with adult asthma (Unoki et al., 2000) and atopic asthma in children (Leung et al., 2002). A suggestive association between rs8113232 in TBXA2R and rhinitis in asthmatic children has been also reported (Kavalar et al., 2012). Finally, the TBXA2R 4684T allele is associated with lower TBXA2R expression, which may contribute to the development of NSAIDs-exacerbated cutaneous disease (NECD) (Palikhe et al., 2011).

\section{LTB4R1 and LTB4R2}

Gene structure analysis of lung samples has revealed that both LTB4R1 and LTB4R2 show splice variation in the $5^{\prime}$-UTR and multiple promoter regions, although they did not find susceptibility markers for asthma development (Tulah et al., 2012). A previous study failed to associate polymorphisms spanning the $L T B R$ locus with baseline lung function in smokers (Tulah et al., 2011).

Increased cytotoxicity and migration of NK cells appears to be linked to LTB4 (Wang et al., 2015). However, there is a differential role for its two receptors. Using a selective receptor antagonist, LTB4R1 was shown to be involved in both LTB4-induced migration and cytotoxicity, whereas LTB4R2 was involved exclusively in NK cell migration, but only in response to higher concentrations of LTB4. The expression of these two receptors increased after activation of NK cells with IL-2 and IL15 , and these changes in expression were reflected in enhanced NK cell responses to LTB4 (Wang et al., 2015).

\section{CYSLTR1 and CYSLTR2}

The functional variant G300S in CYSLTR1 was associated with atopy in the Tristan da Cunha population (Thompson et al., 2007) as the M201V SNP in CYSLTR2 was previously (Thompson et al., 2003). The G300S association has been replicated in another study showing that LTD4-induced phosphorylation of Erk is higher in transfected cells (Yaddaden et al., 2016).

Significant differences in genotype frequencies of the CYSLTR1 promoter polymorphism $-634 \mathrm{C}>\mathrm{T}$ have been associated with clinical requirement for leukotriene receptor antagonists (Kim et al., 2007a). In addition, patients with the variant genotype showed higher expression levels of CYSLTR1 than those with the common genotype (Kim et al., 2007a).

The rs320995 variant in CYSLTR1 has been associated with asthma in two independent studies in Spain (Arriba-Mendez et al., 2006; Sanz et al., 2006). Although a UK study involving 341 families could not find this association, it was linked to atopy severity in females (Hao et al., 2006).

A significant association between the coding polymorphism $601 \mathrm{~A}>\mathrm{G}$ in CYSLTR2 and asthma was observed in a familybased study of asthmatics from Denmark and USA, with the G allele appearing to be less frequently transmitted to asthmatics (Pillai et al., 2004). Using a calcium mobilization assay the authors demonstrated that carriers of the G allele, LTD4 was approximately five-fold less potent compared to wild type, suggesting a potential mechanism for resistance to asthma (Pillai et al., 2004).

A transmission disequilibrium test of 137 Japanese asthmatic families showed that the $-1220 \mathrm{~A}>\mathrm{C}$ SNP in CYSLTR2 was associated with asthma development and with atopic asthma in Japan (Fukai et al., 2004).

The mRNA and protein expression of CYSLT1R and CYSLT2R was found to be significantly increased in polyp tissues from eosinophilic chronic rhinosinusitis patients, and this increase was shown to be related to LTC4 and LTD4 levels (Wu et al., 2016). CYSLTR2 is expressed in the lungs of asthmatics and its activation appears to contribute to antigen-induced bronchoconstriction in certain asthma populations (Sekioka et al., 2015).

\section{PTG, TBXA2, AND LT RECEPTOR POLYMORPHISMS IN NSAID HYPERSENSITIVITY}

NSAIDs, commonly used in the treatment of pain and some inflammatory diseases, are the main triggers of drug hypersensitivity reactions (Conaghan, 2012). The most frequent type of reaction caused by these drugs is cross-intolerance, in which COX-1 inhibition leads to CysLTs release, resulting in clinical symptoms in susceptible individuals (Doña et al., 2011, 2012, 2014). Three main phenotypes of cross-intolerance are currently recognized: NERD (previously known as aspirininduced asthma and ASA triad), in patients with rhinitis and/or asthma with/without nasal polyposis; NECD (previously known as aspirin-intolerant chronic urticaria), in patients with underlying chronic idiopathic urticaria; and NSAIDs-induced urticaria/angioedema (NIUA) in otherwise healthy individuals (Kowalski et al., 2013).

Recent years have witnessed increased interest in the potential role of SNPs in these pathologies. We will now focus on those variants related to PTG and LT receptors.

\section{PTGFR, PTGIR, PTGDR, and CRTH2}

Most genetic association studies have not further investigated the functional effects of associated variants, for example, the 1915 T $>$ C variant in PTGIR that has been associated with NERD 
in Korea, however the mechanisms by which it leads to the pathology are unclear (Kim et al., 2007b).

Although the PTGDR -549T>C (rs8004654) SNP could not been shown to be associated with NERD in a Korean population (Kim et al., 2007b), we recently found an association between NIUA, the most common type of drug hypersensitivity reactions, and this polymorphism in two independent Spanish populations (Cornejo-Garcia et al., 2012). In terms of potential mechanism, it has been shown that the $\mathrm{C}$ allele (risk for NIUA in our study) increases GATA-2/GATA-3 transcription factor binding, modifying promoter activity and PTGDR gene expression (Oguma et al., 2004). Interestingly, given that an association could not be found in the Korean study mentioned above, this variant has also been associated with NERD in Spain (Ayuso et al., 2015).

In patients with NERD the CRTH2 $-466 \mathrm{~T}>\mathrm{C}$ polymorphism increases both serum and cellular eotaxin- 2 production, and may lead to eosinophilic infiltration in these patients (Palikhe et al., 2010). Another study also showed that the frequency of the homozygous genotype for the less frequent allele of CRTH2 -466T $>$ C was higher in NERD patients compared to aspirin-tolerant asthmatics (Kohyama et al., 2012). Interestingly, homozygous TT chronic urticaria patients required higher doses of antihistamines (Palikhe et al., 2009).

\section{PTGE Receptors}

Two promoter variants (rs3810253 and rs3810255) in PTGER1 have recently been found to be associated with NERD, although their functional consequences need to be elucidated (Ayuso et al., 2015).

We have found that the rs 1254598 polymorphism in PTGER2 was marginally associated with NERD patients when compared with NSAID-tolerant asthmatics (Ayuso et al., 2015). In addition, two promoter variants in PTGER2 $(-616 \mathrm{C}>\mathrm{G}$ and $-166 \mathrm{G}>\mathrm{A})$ have been associated with NERD in a Korean population (Kim et al., 2007b).

It has been shown that in patients with NECD the GG genotype at $-1254 \mathrm{G}>\mathrm{A}$ in PTGER4 is more frequent than in healthy individuals (Palikhe et al., 2012). In addition, the $G$ allele leads to lower in vitro promoter activity with decreased PTGER4 expression (Palikhe et al., 2012). This promoter polymorphism $(-1254 \mathrm{~A}>\mathrm{G})$ has also been reported to be associated with NERD in Koreans (Kim et al., 2007b). However, recent research failed to demonstrate an association between NIUA and two promoter variants in PTGER4 (rs13186505 and rs4133101) in a Spanish population (Cornejo-Garcia et al., 2012). In addition, no statistically significant association was found for another variant in PTGER4 (rs4495224) in NERD patients (Ayuso et al., 2015).

\section{TXA2R}

The frequencies of the CC/CT genotype of TBXA2R 795T $>C$ were higher than those of the TT genotype in NERD patients compared to ASA-tolerant asthmatics (Kohyama et al., 2012). TBXA2R $-4684 \mathrm{C}>\mathrm{T}$ and $795 \mathrm{~T}>\mathrm{C}$ variants have also been associated with NERD (Kim et al., 2007b).

\section{CYSLTR1 and CYSLTR2}

Male NERD patients showed higher frequencies of the minor alleles of $-634 \mathrm{C}>\mathrm{T},-475 \mathrm{~A}>\mathrm{C},-336 \mathrm{~A}>\mathrm{G}$ polymorphisms in CYSLTR1 than male controls (Kim et al., 2006). In addition, the haplotype [T-C-G] was associated with increased disease risk for NERD and also affected gene expression, measured by significantly enhanced luciferase activity (Kim et al., 2006). The $-634 \mathrm{C}>\mathrm{T}$ SNP was also most frequent in NERD compared to NECD patients and the variant genotype showed significantly higher promoter activity than the common genotype (Kim et al., 2007c).

The CYSLTR1 variant rs320995 was associated with NIUA in two independent Spanish populations (Cornejo-Garcia et al., 2012). It has also been associated with NERD in Spain (Yaddaden et al., 2016), but not with NERD in Korea (Choi et al., 2004).

Finally, NERD patients carrying the minor alleles for $819 \mathrm{~T}>\mathrm{G}, 2078 \mathrm{C}>\mathrm{T}$ or $2534 \mathrm{~A}>\mathrm{G}$ in CYLSTR2 exhibited a more pronounced fall in FEV1 after aspirin provocation than those who carried the common allele (Park et al., 2005).

\section{FUTURE DIRECTIONS}

Important international efforts such as HapMap and the 1000 Genomes projects, as well as advances in in silico analysis have led to substantial advances in our knowledge of the human genome and its relationship with disease. This will almost certainly increase in the near future through the adoption of nextgeneration sequencing approaches for the discovery of associated variants, and the integration of the different omics technologies, such as transcriptomics, metabolomics, and lipidomics, which will help us to uncover the underlying mechanisms behind complex human diseases.

Focusing on GPCRs, a number of public databases integrating genome data and in silico predictions are currently available and have been recently reviewed (Thompson et al., 2014). Four recommended computational tools for predicting the functional effects of SNPs on protein structure and function are PolyPhen (http://genetics.bwh.harvard.edu/pph2), SIFT (http:// sift.jcvi.org), SNAP (https://www.broadinstitute.org/mpg/snap), and Mutation Taster (http://www.mutationtaster.org).

Mediators from the arachidonic acid pathway play a key role in inflammation as well as in the pathogenesis of a number of diseases. The lack of agreement in genetic association studies is likely related to population differences, including ethnic genetic background, sample size, and differences in phenotype definitions. In addition, most genetic studies have not addressed rare variants that are thought to be involved in complex diseases together with environmental factors. In spite of these limitations, as technologies improve and international networks and collaborations continue to flourish, we expect our knowledge on the genetic basis of inflammation and other conditions to become more refined, potentially leading to the discovery of markers and treatment options for a range of diseases.

\section{AUTHOR CONTRIBUTIONS}

JC, JP, RJ, NS, and NB revised the literature available on this topic and wrote the first manuscript draft. JC, EG, JA, and EV revised 
the manuscript. JC and JP are responsible of the final English version.

\section{FUNDING}

JC receives funding from the Miguel Servet Program (Ref CP14/00034); JP receives funding the Sara Borrell Program (Ref CD14/00242), both from the Carlos III National Health Institute, Spanish Ministry of Economy and Competitiveness

\section{REFERENCES}

(1997). A genome-wide search for asthma susceptibility loci in ethnically diverse populations. The Collaborative Study on the Genetics of Asthma (CSGA). Nat. Genet. 15, 389-392.

Arriba-Mendez, S., Sanz, C., Isidoro-Garcia, M., Davild, I., Laffond, E., Horeno, E., et al. (2006). 927T $>$ C polymorphism of the cysteinyl-leukotriene type1 receptor (CYSLTR1) gene in children with asthma and atopic dermatitis. Pediatr. Allergy Immunol. 17, 323-328. doi: 10.1111/j.1399-3038.2006.00416.x

Ayuso, P., Plaza-Serón Mdel, C., Blanca-López, N., Doña, I., Campo, P., Canto, E., et al. (2015). Genetic variants in arachidonic acid pathway genes associated with NSAID-exacerbated respiratory disease. Pharmacogenomics 16, 825-839. doi: $10.2217 /$ pgs. 15.43

Benito Pescador, D., Isidoro-García, M., García-Solaesa, V., Pascual de Pedro, M., Sanz, C., Hernández-Hernández, L., et al. (2012). Genetic association study in nasal polyposis. J. Investig. Allergol. Clin. Immunol. 22, 331-340.

Breyer, M. D., and Breyer, R. M. (2000). Prostaglandin E receptors and the kidney. Am. J. Physiol. Renal Physiol. 279, F12-F23.

Cameron, L., Depner, M., Kormann, M., Klopp, N., Illig, T., von Mutius, E., et al. (2009). Genetic variation in CRTh2 influences development of allergic phenotypes. Allergy 64, 1478-1485. doi: 10.1111/j.1398-9995.2009.02053.x

Campos Alberto, E., Maclean, E., Davidson, C., Palikhe, N. S., Storie, J., Tse, C., et al. (2012). The single nucleotide polymorphism CRTh2 rs533116 is associated with allergic asthma and increased expression of CRTh2. Allergy 67, 1357-1364. doi: 10.1111/all.12003

Capra, V., Bäck, M., Angiolillo, D. J., Cattaneo, M., and Sakariassen, K. S. (2014). Impact of vascular thromboxane prostanoid receptor activation on hemostasis, thrombosis, oxidative stress, and inflammation. J. Thromb. Haemost. 12, 126-137. doi: 10.1111/jth.12472

Capra, V., Rovati, G. E., Mangano, P., Buccellati, C., Murphy, R. C., and Sala, A. (2015). Transcellular biosynthesis of eicosanoid lipid mediators. Biochim. Biophys. Acta 1851, 377-382. doi: 10.1016/j.bbalip.2014.09.002

Chai, W., Lian, Z., Chen, C., Liu, J., Shi, L. L., and Wang, Y. (2013). JARID1A, JMY, and PTGER4 polymorphisms are related to ankylosing spondylitis in Chinese Han patients: a case-control study. PLOS ONE 8:e74794. doi: 10.1371/journal.pone.0074794

Choi, J. H., Park, H. S., Oh, H. B., Lee, J. H., Suh, Y. J., Park, C. S., et al. (2004). Leukotriene-related gene polymorphisms in ASA-intolerant asthma: an association with a haplotype of 5-lipoxygenase. Hum. Genet. 114, 337-344. doi: 10.1007/s00439-004-1082-1

Claar, D., Hartert, T. V., and Peebles, R. S. Jr. (2015). The role of prostaglandins in allergic lung inflammation and asthma. Expert Rev. Respir. Med. 9, 55-72. doi: $10.1586 / 17476348.2015 .992783$

Conaghan, P. G. (2012). A turbulent decade for NSAIDs: update on current concepts of classification, epidemiology, comparative efficacy, and toxicity. Rheumatol. Int. 32, 1491-1502. doi: 10.1007/s00296-011-2263-6

Cornejo-García, J. A., Jagemann, L. R., Blanca-López, N., Doña, I., Flores, C., Guéant-Rodriguez, R. M., et al. (2012). Genetic variants of the arachidonic acid pathway in non-steroidal anti-inflammatory drug-induced acute urticaria. Clin. Exp. Allergy 42, 1772-1781. doi: 10.1111/j.1365-2222.2012. 04078.x

Diamond, J. M., Akimova, T., Kazi, A., Shah, R. J., Cantu, E., Feng, R., et al. (2014). Genetic variation in the prostaglandin E2 pathway is associated with (grants co-funded by the European Social Fund, ESF). The present study was supported by grants from the Carlos III National Health Institute, Spanish Ministry of Economy and Competitiveness (grants cofunded by the European Regional Development Fund, ERDF): RD12/0013/0001 (Red de Investigación de Reacciones Adversas a Alérgenos y Fármacos, RIRAAF Network), FIS PI12/02247, FIS PI13/02598, FISPI15/00726; the Andalusian Public Health Service (PI-02792012); and Junta de Extremadura (Grant GR15026, cofounded by European Regional Development Fund, ERDF).

primary graft dysfunction. Am. J. Respir. Crit. Care Med. 189, 567-575. doi: 10.1164/rccm.201307-1283OC

Doña, I., Barrionuevo, E., Blanca-Lopez, N., Torres, M. J., Fernandez, T. D., Mayorga, C., et al. (2014). Trends in hypersensitivity drug reactions: more drugs, more response patterns, more heterogeneity. J. Investig. Allergol. Clin. Immunol. 24, 143-153.

Doña, I., Blanca-López, N., Cornejo-García, J. A., Torres, M. J., Laguna, J. J., Fernández, J., et al. (2011). Characteristics of subjects experiencing hypersensitivity to non-steroidal anti-inflammatory drugs: patterns of response. Clin. Exp. Allergy 41, 86-95. doi: 10.1111/j.1365-2222.2010.03651.x

Doña, I., Blanca-López, N., Torres, M. J., García-Campos, J., García-Nunez, I., Gómez, F., et al. (2012). Drug hypersensitivity reactions: response patterns, drug involved, and temporal variations in a large series of patients. J. Investig. Allergol. Clin. Immunol. 22, 363-371.

Dorris, S. L., and Peebles, R. S. Jr. (2012). PGI2 as a regulator of inflammatory diseases. Mediat. Inflamm. 2012:926968. doi: 10.1155/2012/926968

Fontana, P., Gandrille, S., Remones, V., Dupont, A., Reny, J. L., Aiach, M., et al. (2006). Identification of functional polymorphisms of the thromboxane A2 receptor gene in healthy volunteers. Thromb. Haemost. 96, 356-360. doi: 10.1160/th06-05-0288

Fujiwara, T., Ikeda, M., Esumi, K., Fujita, T. D., Kono, M., Tokushige, H., et al. (2007). Exploratory aspirin resistance trial in healthy Japanese volunteers (J-ART) using platelet aggregation as a measure of thrombogenicity. Pharmacogenomics J. 7, 395-403. doi: 10.1038/sj.tpj.6500435

Fukai, H., Ogasawara, Y., Migita, O., Koga, M., Ichikawa, K., Shibasaki, M., et al. (2004). Association between a polymorphism in cysteinyl leukotriene receptor 2 on chromosome 13q14 and atopic asthma. Pharmacogenetics 14, 683-690. doi: 10.1097/00008571-200410000-00006

Gao, F., Wang, Z. X., Men, J. L., Ren, J., and Wei, M. X. (2011). Effect of polymorphism and type II diabetes on aspirin resistance in patients with unstable coronary artery disease. Chin. Med. J. 124, 1731-1734.

Gao, L. C., Wang, D., Liu, F. Q., Huang, Z. Y., Huang, H. G., Wang, G. H., et al. (2015). Influence of PTGS1, PTGFR, and MRP4 genetic variants on intraocular pressure response to latanoprost in Chinese primary open-angle glaucoma patients. Eur. J. Clin. Pharmacol. 71, 43-50. doi: 10.1007/s00228-014-1769-8

Glas, J., Seiderer, J., Czamara, D., Pasciuto, G., Diegelmann, J., Wetzke, M., et al. (2012). PTGER4 expression-modulating polymorphisms in the 5 p13.1 region predispose to Crohn's disease and affect NF-kappaB and XBP1 binding sites. PLoS ONE 7:e52873. doi: 10.1371/journal.pone.0052873

Gleim, S., Stitham, J., Tang, W. H., Li, H., Douville, K., Chelikani, P., et al. (2013). Human thromboxane A2 receptor genetic variants: in silico, in vitro and "in platelet" analysis. PLOS ONE 8:e67314. doi: 10.1371/journal.pone.0067314

Hakonarson, H., Bjornsdottir, U. S., Halapi, E., Palsson, S., Adalsteinsdottir, E., Gislason, D., et al. (2002). A major susceptibility gene for asthma maps to chromosome 14q24. Am. J. Hum. Genet. 71, 483-491. doi: 10.1086/342205

Hao, L., Sayers, I., Cakebread, J. A., Barton, S. J., Beghe, B., Holgate, S. T., et al. (2006). The cysteinyl-leukotriene type 1 receptor polymorphism 927T/C is associated with atopy severity but not with asthma. Clin. Exp. Allergy 36, 735-741. doi: 10.1111/j.1365-2222.2006.02511.x

Hong, S. J., Lee, S. Y., Kim, H. B., Kim, J. H., Kim, B. S., Choi, S. O., et al. (2005). IL-5 and thromboxane A2 receptor gene polymorphisms are associated with decreased pulmonary function in Korean children with atopic asthma. J. Allergy Clin. Immunol. 115, 758-763. doi: 10.1016/j.jaci.2004.10.047 
Huang, J. L., Gao, P. S., Mathias, R. A., Yao, T. C., Chen, L. C., Kuo, M. L., et al. (2004). Sequence variants of the gene encoding chemoattractant receptor expressed on Th2 cells (CRTH2) are associated with asthma and differentially influence mRNA stability. Hum. Mol. Genet. 13, 2691-2697. doi: $10.1093 / \mathrm{hmg} / \mathrm{ddh} 279$

Isidoro-García, M., Sanz, C., García-Solaesa, V., Pascual, M., Pescador, D. B., Lorente, F., et al. (2011). PTGDR gene in asthma: a functional, genetic, and epigenetic study. Allergy 66, 1553-1562. doi: 10.1111/j.1398-9995.2011.02685.x

Jamrozik, E. F., Warrington, N., McClenaghan, J., Hui, J., Musk, A. W., James, A., et al. (2011). Functional haplotypes in the PTGDR gene fail to associate with asthma in two Australian populations. Respirology 16, 359-366. doi: 10.1111/j.1440-1843.2010.01917.x

Jostins, L., Ripke, S., Weersma, R. K., Duerr, R. H., McGovern, D. P., Hui, K. Y., et al. (2012). Host-microbe interactions have shaped the genetic architecture of inflammatory bowel disease. Nature 491, 119-124. doi: 10.1038/nature11582

Kavalar, M. S., Balantic, M., Silar, M., Kosnik, M., Korosec, P., and Rijavec, M. (2012). Association of ORMDL3, STAT6 and TBXA2R gene polymorphisms with asthma. Int. J. Immunogenet. 39, 20-25. doi: 10.1111/ j.1744-313X.2011.01051.X

Kim, J. H., Lee, S. Y., Kim, H. B., Jin, H. S., Yu, J. H., Kim, B. J., et al. (2008). TBXA2R gene polymorphism and responsiveness to leukotriene receptor antagonist in children with asthma. Clin. Exp. Allergy 38, 51-59. doi: 10.1111/j.1365-2222.2007.02931.x

Kim, S. H., Choi, J. H., Park, H. S., Holloway, J. W., Lee, S. K., Park, C. S., et al. (2005). Association of thromboxane A2 receptor gene polymorphism with the phenotype of acetyl salicylic acid-intolerant asthma. Clin. Exp. Allergy 35, 585-590. doi: 10.1111/j.1365-2222.2005.02220.x

Kim, S. H., Kim, Y. K., Park, H. W., Jee, Y. K., Kim, S. H., Bahn, J. W., et al. (2007b). Association between polymorphisms in prostanoid receptor genes and aspirin-intolerant asthma. Pharmacogenet. Genomics 17, 295-304. doi: 10.1097/01.fpc.0000239977.61841.fe

Kim, S. H., Oh, J. M., Kim, Y. S., Palmer, L. J., Suh, C. H., Nahm, D. H., et al. (2006). Cysteinyl leukotriene receptor 1 promoter polymorphism is associated with aspirin-intolerant asthma in males. Clin. Exp. Allergy 36, 433-439. doi: 10.1111/j.1365-2222.2006.02457.x

Kim, S. H., Yang, E. M., Park, H. J., Ye, Y. M., Lee, H. Y., and Park, H. S. $(2007 \mathrm{c})$. Differential contribution of the CysLTR1 gene in patients with aspirin hypersensitivity. J. Clin. Immunol. 27, 613-619. doi: 10.1007/s10875-0079115-x

Kim, S. H., Ye, Y. M., Hur, G. Y., Lee, S. K., Sampson, A. P., et al. (2007a). CysLTR1 promoter polymorphism and requirement for leukotriene receptor antagonist in aspirin-intolerant asthma patients. Pharmacogenomics 8, 1143-1150. doi: 10.2217/14622416.8.9.1143

Kohyama, K., Hashimoto, M., Abe, S., Kodaira, K., Yukawa, T., Lee, H. Y., et al. (2012). Thromboxane A2 receptor $+795 \mathrm{~T}>\mathrm{C}$ and chemoattractant receptorhomologous molecule expressed on Th2 cells $-466 \mathrm{~T}>\mathrm{C}$ gene polymorphisms in patients with aspirin-exacerbated respiratory disease. Mol. Med. Rep. 5, 477-482. doi: 10.3892/mmr.2011.680

Konya, V., Üllen, A., Kampitsch, N., Theiler, A., Philipose, S., Parzmair G. P., et al. (2013). Endothelial E-type prostanoid 4 receptors promote barrier function and inhibit neutrophil trafficking. J. Allergy Clin. Immunol. 131, 532-540. doi: 10.1016/j.jaci.2012.05.008

Kowalski, M. L., Asero, R., Bavbek, S., Blanca, M., Blanca-Lopez, N., et al. (2013). Classification and practical approach to the diagnosis and management of hypersensitivity to nonsteroidal anti-inflammatory drugs. Allergy 68, 1219-1232. doi: 10.1111/all.12260

Leung, T. F., Li, C. Y., Kong, A. P. S., Chan, I. H. S., Ng, M. C. Y., Chan, M. H., et al. (2009). PTGDR is not a major candidate gene for asthma and atopy in Chinese children. Pediatr. Allergy Immunol. 20, 556-562. doi: 10.1111/j.1399-3038.2008. 00835.x

Leung, T. F., Tang, N. L., Lam, C. W., Li, A. M., Chan, I. H., and Ha, H. G. (2002). Thromboxane A2 receptor gene polymorphism is associated with the serum concentration of cat-specific immunoglobulin $\mathrm{E}$ as well as the development and severity of asthma in Chinese children. Pediatr. Allergy Immunol. 13, 10-17. doi: 10.1034/j.1399-3038.2002.01033.x

Li, J., Liu, Q., Wang, P., Li, H., Wei, C., Guo, C. et al. (2007). Lack of association between three promoter polymorphisms of PTGDR gene and asthma in a
Chinese Han population. Int. J. Immunogenet. 34, 353-357. doi: 10.1111/j.1744313X.2007.00699.x

Libioulle, C., Louis, E., Hansoul, S., Sandor, C., Farnir, F., Franchimont, D., et al. (2007). Novel Crohn disease locus identified by genome-wide association maps to a gene desert on 5p13.1 and modulates expression of PTGER4. PLoS Genet. 3:e58. doi: 10.1371/journal.pgen.0030058

Mansur, A. H., Bishop, D. T., Markham, A. F., Morton, N. E., Holgate, S. T., and Morrison, J. F. (1999). Suggestive evidence for genetic linkage between IgE phenotypes and chromosome 14q markers. Am. J. Respir. Crit. Care Med. 159, 1796-1802. doi: 10.1164/ajrccm.159.6.9804036

Nossent, A. Y., Hansen, J. L., Doggen, C., Quax, P. H., Sheikh, S. P., and Rosendaal, F. R. (2011). SNPs in microRNA binding sites in $3^{\prime}$-UTRs of RAAS genes influence arterial blood pressure and risk of myocardial infarction. Am. J. Hypertens. 24, 999-1006. doi: 10.1038/ajh.2011.92

Oguma, T., Palmer, L. J., Birben, E., Sonna, L. A., Asano, K., and Lilly, C. M. (2004). Role of prostanoid DP receptor variants in susceptibility to asthma. N. Engl. J. Med. 351, 1752-1763. doi: 10.1056/NEJMoa031785

Palikhe, N. S., Kim, S. H., Cho, B. Y., Ye, Y. M., Choi, G. S., and Park, H. S. (2010). Genetic variability in CRTH2 polymorphism increases eotaxin-2 levels in patients with aspirin exacerbated respiratory disease. Allergy 65, 338-346. doi: 10.1111/j.1398-9995.2009.02158.x

Palikhe, N. S., Kim, S. H., Lee, H. Y., Kim, J. H., Ye, Y. M., and Park, H. S. (2011). Association of thromboxane A2 receptor (TBXA2R) gene polymorphism in patients with aspirin-intolerant acute urticaria. Clin. Exp. Allergy 41, 179-185. doi: 10.1111/j.1365-2222.2010.03642.x

Palikhe, N. S., Kim, S. H., Ye, Y. M., Hur, G. Y., Cho, B. Y., and Park, H. S. (2009). Association of CRTH2 gene polymorphisms with the required dose of antihistamines in patients with chronic urticaria. Pharmacogenomics 10, 375-383. doi: 10.2217/14622416.10.3.375

Palikhe, N. S., Sin, H. J., Kim, S. H., Sin, H. J., Hwang, E. K., Ye, Y. M., et al. (2012). Genetic variability of prostaglandin E2 receptor subtype EP4 gene in aspirin-intolerant chronic urticaria. J. Hum. Genet. 57, 494-499. doi: 10.1038/jhg.2012.55

Pan, Y., Li, S., Xie, X., and Li, M. (2016). Association between thromboxane A2 receptor polymorphisms and asthma risk: a meta-analysis. J Asthma 53, 1-29. doi: 10.3109/02770903.2015.1126849

Park, H. W., Shin, E. S., Lee, J. E., Kim, S. H., Kim, S. S., Chang, Y. S., et al. (2007) Association between genetic variations in prostaglandin E2 receptor subtype EP3 gene (Ptger3) and asthma in the Korean population. Clin. Exp. Allergy 37, 1609-1615. doi: 10.1111/j.1365-2222.2007.02820.x

Park, J. S., Chang, H. S., Park, C. S., Lee, J. H., Lee, Y. M., Choi, J. H., et al. (2005). Association analysis of cysteinyl-leukotriene receptor 2 (CYSLTR2) polymorphisms with aspirin intolerance in asthmatics. Pharmacogenet. Genomics 15, 483-492. doi: 10.1097/01.fpc.0000166456.84905.a0

Patrignani, P., Di Febbo, C., Tacconelli, S., Douville, K., Guglielmi, M. D., Horvath, R. J., et al. (2008). Differential association between human prostacyclin receptor polymorphisms and the development of venous thrombosis and intimal hyperplasia: a clinical biomarker study. Pharmacogenet. Genomics 18, 611-620. doi: 10.1097/FPC.0b013e328301a774

Pillai, S. G., Cousens, D. J., Barnes, A. A., Buckley, P. T., Chiano, M. N., Hosking, L. K., et al. (2004). A coding polymorphism in the CYSLT2 receptor with reduced affinity to LTD4 is associated with asthma. Pharmacogenetics 14, 627-633. doi: 10.1097/00008571-200409000-00007

Prager, M., Büttner, J., and Büning, C. (2014). PTGER4 modulating variants in Crohn's disease. Int. J. Colorectal Dis. 29, 909-915. doi: 10.1007/s00384-0141881-3

Ryckman, K. K., Morken, N. H., White, M. J., Velez, D. R., Menon, R., Fortunato, S. J., et al. (2010). Maternal and fetal genetic associations of PTGER3 and PON1 with preterm birth. PLOS ONE 5:e9040. doi: 10.1371/journal.pone.00 09040

Sanz, C., Isidro-García, M., Dávila, I., Moreno, E., Laffond, E., and Lorente, F. (2006). Analysis of 927T > C CYSLTRI and -444A > C LTC4S polymorphisms in patients with asthma. J. Investig. Allergol. Clin. Immunol. 16, 331-337.

Sato, M., Nakayama, T., Soma, M., Aoi, N., Kosuge, K., Haketa, A., et al. (2007). Association between prostaglandin E2 receptor gene and essential hypertension. Prostaglandins Leukot. Essent. Fatty Acids 77, 15-20. doi: 10.1016/j.plefa.2007.04.004 
Sekioka, T., Kadode, M., Fujii, M., Kawabata, K., Abe, T., Horiba, M., et al. (2015). Expression of CysLT2 receptors in asthma lung, and their possible role in bronchoconstriction. Allergol. Int. 64, 351-358. doi: 10.1016/j.alit.2015. 04.008

Shao, J., Fu, Y., Yang, W., Yan, J., Zhao, J., Chen, J., et al. (2015). Thromboxane A2 receptor polymorphism in association with cerebral infarction and its regulation on platelet function. Curr. Neurovasc. Res. 12, 15-24. doi: 10.2174/1567202612666150102125221

Shimizu, M., Yoshimura, S., Takizawa, S., Kohara, S., Inoko, H., and Takagi, S. (2013). Effect of single nucleotide polymorphisms of the prostacyclin receptor gene on platelet activation in Japanese healthy subjects and patients with cerebral infarction. J. Clin. Neurosci. 20, 851-856. doi: 10.1016/j.jocn.2012.06.011

Shin, H. D., Park, B. L., Jung, J. H., Wang, H. J., Park, H. S., Choi, B. W., et al. (2003). Association of thromboxane A2 receptor (TBXA2R) with atopy and asthma. J. Allergy Clin. Immunol. 112, 454-457. doi: 10.1067/mai.20 03.1641

Singh, R. K., Tandon, R., Dastidar, S. G., and Ray, A. (2013). A review on leukotrienes and their receptors with reference to asthma. J. Asthma 50, 922-931. doi: 10.3109/02770903.2013.823447

Sõber, S., Org, E., Kepp, K., Juhanson, P., Eyheramendy, S., Gieger, C., et al. (2009). Targeting 160 candidate genes for blood pressure regulation with a genomewide genotyping array. PLoS ONE 4:e6034. doi: 10.1371/journal.pone.0006034

Soontrapa, K., Honda, T., Sakata, D., Yao, C., Hirata, T., Hori, S., et al. (2011). Prostaglandin E2-prostaglandin E receptor subtype 4 (EP4) signaling mediates UV irradiation-induced systemic immunosuppression. Proc. Natl. Acad. Sci. U.S.A. 108, 6668-6673. doi: 10.1073/pnas. 1018625108

Takeuchi, K., Mashimo, Y., Shimojo, N., Arima, T., Inoue, Y., Morita, Y., et al. (2013). Functional variants in the thromboxane A2 receptor gene are associated with lung function in childhood-onset asthma. Clin. Exp. Allergy 43, 413-424. doi: 10.1111/cea.12058

Tang, E. H., Libby, P., Vanhoutte, P. M., and Xu, A. (2012). Anti-inflammation therapy by activation of prostaglandin EP4 receptor in cardiovascular and other inflammatory diseases. J. Cardiovasc. Pharmacol. 59, 116-123. doi: 10.1097/FJC.0b013e3182244a12

Thompson, M. D., Capra, V., Takasaki, J., Maresca, G., Rovati, G. E., Slutsky, A. S., et al. (2007). A functional G300S variant of the cysteinyl leukotriene 1 receptor is associated with atopy in a Tristan da Cunha isolate. Pharmacogenet. Genomics 17, 539-549. doi: 10.1097/FPC.0b013e328012d0bf

Thompson, M. D., Cole, D. E., Capra, V., Siminovitch, K. A., Rovati, G. E., Burnhman, W. M., et al. (2014). Pharmacogenetics of the G proteincoupled receptors. Methods Mol. Biol. 1175, 189-242. doi: 10.1007/978-1-49390956-8_9

Thompson, M. D., Storm van's Gravesande, K., Galczenski, H., Burnham, W. M., Siminovitch, K. A., Zamel, N., et al. (2003). A cysteinyl leukotriene 2 receptor variant is associated with atopy in the population of Tristan da Cunha. Pharmacogenetics 13, 641-649. doi: 10.1097/00008571-200310000-00008

Tsai, Y. J., Choudhry, S., Kho, J., Beckman, K., Tsai, H. J., Navarro, D., et al. (2006). The PTGDR gene is not associated with asthma in 3 ethnically diverse populations. J. Allergy Clin. Immunol. 118, 1242-1248. doi: 10.1016/j.jaci.2006.07.045

Tulah, A. S., Beghé, B., Barton, S. J., Holloway, J. W., and Sayers, I. (2012). Leukotriene B4 receptor locus gene characterisation and association studies in asthma. BMC Med. Genet. 13:110. doi: 10.1186/1471-2350-13-110
Tulah, A. S., Parker, S. G., Moffatt, M. F., Wardlaw, A. J., Connolly, M. J., and Sayers, I. (2011). The role of ALOX5AP, LTA4H and LTB4R polymorphisms in determining baseline lung function and COPD susceptibility in UK smokers. BMC Med. Genet. 12:173. doi: 10.1186/1471-2350-12-173

Ungvári, I., Hullám, G., Antal, P., Kiszel, P. S., Gézsi, A., Hadadi, E., et al. (2012). Evaluation of a partial genome screening of two asthma susceptibility regions using bayesian network based bayesian multilevel analysis of relevance. PLoS ONE 7:e33573. doi: 10.1371/journal.pone.0033573

Unoki, M., Furuta, S., Onouchi, Y., Watanabe, O., Doi, S., Fujiwara, H., et al. (2000). Association studies of 33 single nucleotide polymorphisms (SNPs) in 29 candidate genes for bronchial asthma: positive association a T924C polymorphism in the thromboxane A2 receptor gene. Hum. Genet. 106, 440-446. doi: 10.1007/s004390000267

Ussa, F., Fernandez, I., Brion, M., Carracedo, A., Blazquez, F., García, M. T., et al. (2015). Association between SNPs of metalloproteinases and prostaglandin F2alpha receptor genes and latanoprost response in open-angle glaucoma. Ophthalmology 122, 1040-1048. doi: 10.1016/j.ophtha.2014.12.038

Wang, J., Xu, Y., Zhao, H., Sui, H., Liang, H., Jiang, X., et al. (2009). Genetic variations in chemoattractant receptor expressed on Th2 cells (CRTH2) is associated with asthma susceptibility in Chinese children. Mol. Biol. Rep. 36, 1549-1553. doi: 10.1007/s11033-008-9349-6

Wang, M., Mostafa El-Maghraby, N., Turcotte, S., Rola-Pleszczynski, M., and Stankova, J. (2015). Differential Contribution of BLT1 and BLT2 to Leukotriene B4-Induced Human NK Cell Cytotoxicity and Migration. Mediat. Inflamm. 2015:389849. doi: 10.1155/2015/389849

Wang, Z., Gao, F., Men, J., Yang, J., Modi, P., and Wei, M. (2013). Polymorphisms and high on-aspirin platelet reactivity after off-pump coronary artery bypass grafting. Scand. Cardiovasc. J. 47, 194-199. doi: 10.3109/14017431.2013.800640

Wu, X., Hong, H., Zuo, K., Han, M., Li, J., Wen, W. et al. (2016). Expression of leukotriene and its receptors in eosinophilic chronic rhinosinusitis with nasal polyps. Int. Forum Allergy Rhinol. 6, 75-81. doi: 10.1002/alr.21625

Yaddaden, L., Véronneau, S., Thompson, M. D., Rola-Pleszczynski, M., and Stankova, J. (2016). Cellular signalling of cysteinyl leukotriene type 1 receptor variants CysLT1-G300S and CysLT1-I206S. Prostaglandins Leukot. Essent. Fatty Acids 105, 1-8. doi: 10.1016/j.plefa.2015.12.004

Zhao, J., Zheng, L., Fei, Q., Fu, Y., Weng, Y., Wu, H., et al. (2013). Association of thromboxane A2 receptor gene polymorphisms with cerebral infarction in a Chinese population. Neurol. Sci. 34, 1791-1796. doi: 10.1007/s10072-0131340-x

Zhu, G., Vestbo, J., Lenney, W., Silverman, M., Whyte, M., Helms, P., et al. (2007). Association of PTGDR gene polymorphisms with asthma in two Caucasian populations. Genes Immun. 8, 398-403. doi: 10.1038/sj.gene.6364399

Conflict of Interest Statement: The authors declare that the research was conducted in the absence of any commercial or financial relationships that could be construed as a potential conflict of interest.

Copyright (c) 2016 Cornejo-García, Perkins, Jurado-Escobar, García-Martín, Agúndez, Viguera, Pérez-Sánchez and Blanca-López. This is an open-access article distributed under the terms of the Creative Commons Attribution License (CC BY). The use, distribution or reproduction in other forums is permitted, provided the original author(s) or licensor are credited and that the original publication in this journal is cited, in accordance with accepted academic practice. No use, distribution or reproduction is permitted which does not comply with these terms. 